Finanse, Rynki Finansowe, Ubezpieczenia nr 3/2017 (87), cz. 1

\title{
Czynniki kształtujące koszty funkcjonowania audytu wewnętrznego
}

\begin{abstract}
Adam Bujak*
Streszczenie: $\mathrm{Cel}$ - Identyfikacja oraz scharakteryzowanie czynników wpływających na koszty przeprowadzania działań audytowych, które mogą być wykorzystane do analizy efektywności audytu wewnętrznego. Metodologia badania - Dokonano przeglądu literatury przedmiotu, zastosowano również ogólną metodę dedukcyjną.

Wynik - Szczegółowo scharakteryzowano czynniki, które decydują o kosztach funkcjonowania audytu wewnętrznego, zidentyfikowano wzajemne zależności występujące między nimi, wymieniono również potencjalne koszty związane z prowadzeniem audytu wewnętrznego.

Oryginalność/wartość - Racjonalne zarządzanie audytem wewnętrznym wymaga znajomości kosztów związanych z tą sferą działalności. Należy więc tak kształtować ich poziom, aby je optymalizować, czyli w pełni realizować cele audytu, ponosząc przy tym najniższe koszty.
\end{abstract}

Słowa kluczowe: audyt wewnętrzny, efektywność, determinanty efektywności, koszty

\section{Wprowadzenie}

Współcześnie coraz większe znaczenie przypisuje się efektywności. Aby dana organizacja mogła funkcjonować efektywnie, powinna osiągać zamierzone cele w sposób zgodny z zasadą racjonalnego gospodarowania (Skrzypek, 2000), według której oczekiwane efekty należy uzyskiwać jak najmniejszym kosztem, względnie maksymalizować je przy danych nakładach (Gabrusewicz, Kamela-Sowińska, Poetschke, 2002). Działalność prowadzona przez różnego typu podmioty, zaliczane zarówno do sektora prywatnego, jak i publicznego, musi być stale monitorowana. Ważne jest przy tym, by weryfikowany był sposób, w jaki to następuje. W tym procesie istotną rolę pełni audyt wewnętrzny, którego celem jest przysporzenie wartości i usprawnienie działalności operacyjnej organizacji poprzez systematyczną i dokonywaną w uporządkowany sposób ocenę procesów zarządzania ryzykiem, kontroli i ładu organizacyjnego, przyczyniającą się do poprawy ich funkcjonowania, a także doradztwo w tym zakresie (Definicja audytu..., 2016).

Audyt wewnętrzny generuje jednak koszty. Z punktu widzenia podmiotu audytowanego powinny być one optymalne, czyli możliwie niskie, przy zagwarantowaniu odpowiedniego poziomu jakości audytu. Koszty należy kontrolować, ale może to nastąpić dopiero wtedy,

\footnotetext{
* dr Adam Bujak, Uniwersytet Marii Curie-Skłodowskiej w Lublinie, Wydział Ekonomiczny, Zakład Rachunkowości, e-mail: abujak@hektor.umcs.lublin.pl.
} 
gdy zidentyfikowane zostaną bezpośrednie przyczyny ich ponoszenia. Za cel niniejszego artykułu przyjęto zidentyfikowanie takich przyczyn oraz kosztów, jakie one generują. Realizacja celu wymagała zastosowania ogólnej metody dedukcyjnej oraz analizy literatury przedmiotu. Determinantami kosztów audytu wewnętrznego są:

- obowiązujące standardy i regulacje prawne,

- czynniki organizacyjne,

- zasoby majątkowe,

- zasoby kadrowe.

\section{Obowiązujące standardy i regulacje prawne}

Przeprowadzanie audytu wewnętrznego powinno podlegać określonym regułom, przy czym potrzeba ich opracowania wynika $z$ upowszechniania audytu i poszukiwania uniwersalnych sposobów, które mogłyby być wielokrotnie stosowane w celu eliminacji potencjalnie pojawiających się problemów (por. Ustawa z 12 września 2002 r. o normalizacji; Dz.U. 2015, poz. 1483). Następuje więc standaryzacja przejawiająca się tworzeniem identycznych rozwiązań, których wykorzystywanie przez różne podmioty ma na celu doskonalenie ich funkcjonowania (Gos, 2013).

Za najważniejsze wytyczne związane z przeprowadzaniem audytu uznać należy Międzynarodowe Standardy Praktyki Zawodowej Audytu Wewnętrznego (Definicja audytu..., 2016), które odnoszą się do takich kwestii, jak sposób dokumentowania, metodyka, organizacja oraz pożądane efekty działań audytowych. Należy jednak nadmienić, że mają one charakter ramowy, w związku z czym dopasowane są do różnych typów organizacji oraz pozostawiają pewien zakres swobody dotyczący sposobu przeprowadzania audytu. W przywołanych standardach podkreśla się, że ich przestrzeganie warunkuje wypełnianie obowiązków audytora wewnętrznego.

Rozpatrując znaczenie standardów przez pryzmat efektywności audytu można stwierdzić, że nie wymuszają one ponoszenia konkretnych kosztów. Zapewnienie zgodności ze standardami wymaga jednak sporządzania właściwej dokumentacji, zatrudnienia odpowiednio przygotowanych specjalistów, a także określonych metod działania, co nie pozostaje już bez wpływu na rodzaj i wartość wykorzystywanych zasobów.

Standardy należy stosować we wszystkich podmiotach przeprowadzających audyt, niezależnie od tego, czy zaliczają się one do sfery prywatnej czy też nie. Dla jednostek sektora finansów publicznych mają one jednak charakter obligatoryjny, wynikający z przepisów prawa. Podmioty, które muszą, bądź mogą, przeprowadzać audyt wewnętrzny, określa art. 274 ustawy o finansach publicznych (Dz.U. 2016, poz. 1870 z późn. zm.). Sama ustawa nie odwołuje się bezpośrednio do standardów międzynarodowych, ale zawiera delegację dla Ministra Finansów do wydania komunikatu w tym zakresie. $Z$ tego względu moc obowiązująca standardów wynika z komunikatu Ministra Rozwoju i Finansów w sprawie standardów 
audytu wewnętrznego dla jednostek sektora finansów publicznych (Dz. Urz. Min. Rozw. i Fin. 2016, poz. 28).

Dodatkowo kwestie związane z audytem w sferze publicznej uszczegóławiane są przez dwa inne akty wykonawcze:

1. Rozporządzenie Ministra Finansów w sprawie audytu wewnętrznego oraz informacji o pracy i wynikach tego audytu (Dz.U. 2015, poz. 1480 z późn. zm.).

2. Rozporządzenie Ministra Finansów w sprawie komitetu audytu (Dz.U. 2016, poz. 2049). Regulacje zawarte w przywołanych rozporządzeniach wykraczają poza opisywane standardy, np. w odniesieniu do sporządzanej dokumentacji (obejmującej dodatkowo m.in. dokumenty robocze oraz sprawozdania), harmonogramu przeprowadzania audytu, podejmowanych działań (choć w stosunkowo wąskim zakresie), a także zasad nadzoru nad komórkami audytu i ogółem prowadzonych przez nie prac.

Dość szeroka skala unormowań, szczególnie odnoszących się do podmiotów sektora publicznego, nie pozostaje bez wpływu na efektywność audytu wewnętrznego. Przepisy wymuszają bowiem wykonywanie kosztownych działań, które prawdopodobnie nie wystąpiłyby w sytuacji braku prawnego obowiązku. Należy zaznaczyć, że wpływają one także na inne czynniki uznane za determinanty efektywności audytu, głównie związane ze sposobem jego organizacji oraz wykorzystywanymi zasobami kadrowymi.

\section{Czynniki organizacyjne}

Przeprowadzanie audytu wewnętrznego wymaga odpowiedniego zorganizowania całokształtu związanych z nim działań. Organizować to układać coś w pewne formy, podporządkowywać regułom, normom, wprowadzać do czegoś ład (Dubisz, 2003). Organizację audytu wewnętrznego należy więc traktować jako ogół sposobów działania pozwalających na właściwe powiązanie czynności wykonywanych przez poszczególne osoby oraz wykorzystywanych do tego urządzeń, uwzględniając realizację celów audytu przy racjonalnym zaangażowaniu zasobów majątkowych i kadrowych.

Organizację audytu wewnętrznego rozpatrywać można na dwóch płaszczyznach. Pierwsza dotyczy sposobu wykonywania zadań audytowych, druga natomiast umiejscowienia działów zajmujących się audytem w strukturze danego podmiotu. Realizacja poszczególnych zadań wymaga uprzedniego wskazania - kto, jakie czynności i w jaki sposób (a więc przy użyciu jakich technik i narzędzi) powinien wykonać. Konieczne jest zatem określenie w szczególności (por. Podręcznik audytu..., 2003):

- procedur funkcjonowania komórek audytu wewnętrznego (w zakresie planowania, kontroli i raportowania, ale także nadzoru nad audytorami),

- zasobów niezbędnych do przeprowadzenia audytu (kadrowych i majątkowych),

- zakresu odpowiedzialności audytorów (w tym powołania kierownika komórki audytu, czy koordynatorów zadań),

- sposobu dokumentowania pracy, 
- zasad współpracy i wymiany informacji z kierownictwem oraz innymi komórkami organizacyjnymi,

- mechanizmów koordynacji prac, uwzględniając przy tym ewentualne działania audytorów zewnętrznych oraz innych służb kontrolnych.

Sposób funkcjonowania komórek audytu musi być zgodny z obowiązującymi przepisami i standardami, a także odpowiadać wewnętrznym procedurom kontroli efektywności i skuteczności podejmowanych działań (Szymańska, 2013).

Istotnym zagadnieniem jest również umiejscowienie komórek zajmujących się audytem wewnętrznym w strukturze organizacyjnej, co powinno gwarantować niezależność (Definicja audytu..., 2016) i możliwość wykonywania wszelkich zadań związanych z audytem. W praktyce komórka audytu wewnętrznego powinna podlegać bezpośrednio kierownikowi danej jednostki (Szymańska, 2013). Wymaga tego również ustawa o finansach publicznych (Dz.U. 2016, poz. 1870 z późn. zm.). Możliwe są dwa modele rozwiązań w tym zakresie wewnętrzny i zewnętrzny.

Model wewnętrzny polega na realizowaniu zadań związanych $\mathrm{z}$ audytem we własnym zakresie. Model zewnętrzny należy wiązać z outsourcingiem, czyli powierzeniem wykonywania tego rodzaju działalności odrębnemu podmiotowi, który przez to staje się specyficzną komórką organizacyjną, na co zezwala również ustawa o finansach publicznych (Dz.U. 2016, poz. 1870 z późn. zm.). Oczywiście każde z opisanych rozwiązań ma swoje mocne i słabe strony, a najistotniejsze z nich wymieniono w tabeli 1 .

\section{Tabela 1}

Cechy charakterystyczne modelowych rozwiązań w zakresie organizacji komórek audytu wewnętrznego

\begin{tabular}{ll}
\hline Model wewnętrzny & Model zewnętrzny \\
\hline Zalety: & Zalety: \\
- szybki dostęp do wyników audytu, & - działalność audytorska jest kluczową umiejętnością \\
- elastyczność działania (związana z możliwością & partnera, \\
przydzielania zasobów do wykonywania zadań & - dostęp do najlepszych zasobów, \\
najistotniejszych w danym momencie), & - swoboda wyboru partnera, \\
- wysoki poziom bezpieczeństwa informacji, & - pozyskanie zewnętrznych źródeł finansowania \\
ponieważ są one generowane i wykorzystywane & (do czasu zapłaty za usługę wszelkie czynności \\
w danej jednostce & finansuje partner) \\
\hline Wady: & Wady: \\
- organizacyjne uzależnienie komórki audytu & - utrudniony dostęp do bieżących informacji \\
od kierownictwa danej jednostki, które może & dotyczących działań wykonywanych w ramach \\
wpływać na zakres wykonywanych zadań & audytu, \\
audytowych, & - niepełna znajomość specyfiki działalności danej \\
konieczność dysponowania wykwalifikowanym & jednostki przez partnera, \\
personelem, & - potencjalne problemy dotyczące wzajemnej \\
- okresowe trudności z dopasowaniem zasobów & współpracy na linii usługodawca-usługobiorca, \\
(zarówno kadrowych, jak i majątkowych) & - informacje o sposobach funkcjonowania jednostki \\
do aktualnych potrzeb & przekazywane są na zewnątrz \\
\hline
\end{tabular}

Źródło: opracowanie własne. 
Potencjalne problemy, jakie pojawiają się w związku z wykorzystywaniem modelu wewnętrznego lub zewnętrznego powodują, że w praktyce funkcjonować mogą również rozwiązania mieszane. Przykładowo wybrane zadania audytowe wykonywane są przez osoby zatrudnione w danej jednostce, a inne, wymagające szczególnej wiedzy i doświadczenia, realizuje zewnętrzny podmiot. Należy też nadmienić, że w żadnym przypadku audytor nie dysponuje uprawnieniami władczymi w odniesieniu do pracowników jednostek podlegających audytowi (Szymańska, 2013). Nie może więc on wydawać decyzji, które wiążą się z wykorzystywaniem służbowej podległości w relacjach kierownik-podwładny.

Stosowane zasady organizacji audytu wewnętrznego bezpośrednio wpływają na jego efektywność, ponieważ decydują o wielkości ponoszonych nakładów. Przykładowo, w modelu wewnętrznym na pierwszy plan wysuną się koszty związane z zatrudnieniem (wynagrodzenia, ubezpieczenia społeczne i inne świadczenia), z kolei model zewnętrzny będzie charakteryzował się występowaniem kosztów usług obcych. Należy podkreślić, że organizacja audytu jest procesem ciągłym, może więc ulegać zmianom i być dostosowywana do różnych uwarunkowań.

\section{Zasoby majątkowe}

Osiąganie celów stawianych przed audytem wewnętrznym wymaga dysponowania odpowiednim majątkiem. Można korzystać zarówno z zasobów własnych, jak i innych podmiotów, jeśli tylko zostanie to uznane za rozwiązanie korzystniejsze.

Ważne jest, aby uniknąć przypadkowości w doborze składników majątkowych, dlatego też należy dokładnie określić je już w fazie wstępnej audytu, obejmującej planowanie zadań do realizacji. Wykorzystywane są zarówno składniki majątku trwałego, jak i obrotowego. Aktywa trwałe tworzą ogólne ramy, bez których nie jest możliwe wykonywanie zadań audytowych, a do grupy tej zalicza się rzeczowe aktywa trwałe oraz wartości niematerialne i prawne. Wśród aktywów trwałych należałoby, biorąc za podstawę klasyfikację wprowadzoną ustawą o rachunkowości (Dz.U. 2016, poz. 1047 z późn. zm.), wyróżnić:

- budynki, lokale, w tym również wyodrębnione ich części,

- urządzenia techniczne, m.in. komputery, monitory, drukarki, telefony, kserokopiarki,

- środki transportu, np. samochody osobowe wykorzystywane przez audytorów,

- inne środki trwałe, które obejmują niewymienione wcześniej składniki majątku, np. elementy wyposażenia (meble biurowe).

Wartości niematerialne i prawne to przede wszystkim oprogramowanie komputerowe wykorzystywane w trakcie audytu, choć za ich składnik uznać można również know-how, czyli wiedzę o charakterze poufnym lub tajnym nabytą od innego podmiotu, przydatną w działalności audytowej.

Wykorzystywanie aktywów trwałych jest bezpośrednią przyczyną powstawania kosztów audytu wewnętrznego, a ich ogólną charakterystykę zaprezentowano w tabeli 2. 


\section{Tabela 2}

Charakterystyka kosztów audytu wewnętrznego generowanych przez składniki aktywów trwałych

\begin{tabular}{|c|c|c|}
\hline $\begin{array}{l}\text { Grupa aktywów } \\
\text { trwałych }\end{array}$ & $\begin{array}{l}\text { Podgrupa aktywów } \\
\text { trwałych }\end{array}$ & Rodzaje generowanych kosztów \\
\hline \multirow{2}{*}{$\begin{array}{l}\text { Wartości } \\
\text { niematerialne } \\
\text { i prawne }\end{array}$} & $\begin{array}{l}\text { oprogramowanie } \\
\text { komputerowe }\end{array}$ & $\begin{array}{l}\text { amortyzacja, opłaty licencyjne, obsługa serwisowa, aktualizacja, } \\
\text { odsetki od kredytów zaciągniętych na zakup oprogramowania }\end{array}$ \\
\hline & know-how & $\begin{array}{l}\text { amortyzacja, opłaty licencyjne, odsetki od kredytów zaciągniętych } \\
\text { na zakup know-how }\end{array}$ \\
\hline \multirow[t]{4}{*}{$\begin{array}{l}\text { Rzeczowe aktywa } \\
\text { trwałe }\end{array}$} & $\begin{array}{l}\text { budynki, } \\
\text { lokale, w tym } \\
\text { wyodrębnione ich } \\
\text { części }\end{array}$ & $\begin{array}{l}\text { czynsze, amortyzacja, bieżąca eksploatacja (ogrzewanie, } \\
\text { oświetlenie, utrzymanie czystości itp.), remonty, ubezpieczenia, } \\
\text { opłaty leasingowe w części obciążającej koszty, odsetki od kredytów } \\
\text { zaciągniętych na zakup budynków lub lokali }\end{array}$ \\
\hline & $\begin{array}{l}\text { urządzenia } \\
\text { techniczne }\end{array}$ & $\begin{array}{l}\text { amortyzacja, bieżąca eksploatacja (energia, materiały } \\
\text { eksploatacyjne, przeglądy itp.), naprawy, ubezpieczenia, opłaty } \\
\text { leasingowe w części obciążającej koszty, odsetki od kredytów } \\
\text { zaciągniętych na zakup urządzeń technicznych }\end{array}$ \\
\hline & środki transportu & $\begin{array}{l}\text { amortyzacja, bieżąca eksploatacja (paliwo, wymiana części } \\
\text { wynikająca z normalnego użytkowania, przeglądy okresowe } \\
\text { i rejestracyjne, opłaty za miejsca parkingowe itp.), naprawy, } \\
\text { ubezpieczenia, odsetki od kredytów zaciągniętych na zakup środków } \\
\text { transportu }\end{array}$ \\
\hline & inne środki trwałe & $\begin{array}{l}\text { amortyzacja, naprawy, ubezpieczenia, opłaty leasingowe w części } \\
\text { obciążającej koszty, odsetki od kredytów zaciągniętych na zakup } \\
\text { innych środków trwałych }\end{array}$ \\
\hline
\end{tabular}

Źródło: opracowanie własne.

Przeprowadzanie audytu wewnętrznego nie jest ponadto możliwe bez wykorzystania składników aktywów obrotowych. Z uwagi na to, że audyt jest segmentem działalności administracyjnej, przyczynia się przede wszystkim do zużycia materiałów biurowych.

\section{Zasoby kadrowe}

Na efektywność audytu w konkretnej jednostce wpływa personel bezpośrednio zaangażowany w jego funkcjonowanie. Audytor powinien być przygotowany do pełnienia swojej roli. W podmiotach prywatnych może być nim każdy, ponieważ nie ma określonych krajowych wymagań prawnych w tym zakresie. W sektorze publicznym audytor musi natomiast m.in. mieć odpowiednie wykształcenie oraz kwalifikacje potwierdzone np. certyfikatami (Ustawa z 27 sierpnia 2009 r. o finansach publicznych, Dz.U. 2016, poz. 1870 z późn. zm.). Dodatkowo osoby zajmujące się audytem powinny spełniać wymagania zawarte w Kodeksie etyki, takie jak prawość (uczciwość), obiektywizm, poufność oraz kompetencje. Kompetencje należy wiązać nie tylko z przygotowaniem merytorycznym, ale również z nieustannym doskonaleniem biegłości zawodowej, skuteczności i podnoszeniem jakości wykonywanej pracy (Definicja audytu..., 2016). 
W przypadku, gdy podmiot stosuje model wewnętrzny, wyodrębniona komórka audytu może być jedno- lub wieloosobowa. Jeśli audytor jest jeden, wtedy niejako automatycznie pełni on rolę kierownika. $\mathrm{W}$ innych wypadkach kierownik powinien zostać powołany. Odpowiedzialność kierowników sprowadza się przede wszystkim do zapewnienia (Podręcznik audyu..., 2003):

- realizacji celów audytu,

- efektywnego i skutecznego wykorzystania dostępnych zasobów,

- zgodności podejmowanych działań z prawem i obowiązującymi standardami.

Audytorom mogą być również przydzielane funkcje koordynatorów zadań audytowych, jeśli wykonanie danego zadania wymaga zaangażowania większej liczby osób. Koordynatorzy nadzorują wtedy działania podejmowane przez podwładnych w obrębie przyznanej im odpowiedzialności za konkretne obszary audytu, skupiając się na opracowaniu planów, wykonaniu zaplanowanych zadań oraz przygotowaniu właściwych sprawozdań. Audytorzy umiejscowieni najniżej w hierarchii przeprowadzają konkretne czynności audytorskie w ramach powierzonych im zadań (Podręcznik audytu..., 2003). Umiejscowienie pracowników na różnych poziomach w hierarchii organizacyjnej komórki audytu powinno wynikać z cech charakteru poszczególnych osób. Specyfika wykonywanych zadań wymaga przykładowo od kierowników umiejętności logicznego, analitycznego i twórczego myślenia, a także zdolności organizatorskich. Od „zwykłych” audytorów oczekuje się natomiast zręcznego wykonywania konkretnych czynności, a także doskonałej znajomości procesów zachodzących w audytowanej jednostce.

W komórce audytu wewnętrznego może więc wystąpić kilka szczebli kierowniczych. Dowolność w zakresie organizacji tych komórek wynika z tego, że dotychczas nie zostały ustalone żadne normy odnoszące się do ich struktury organizacyjnej czy liczby zatrudnionych audytorów (Szymańska, 2013).

Wykorzystanie czynnika pracy wiąże się z ponoszeniem kosztów wynagrodzeń wraz z narzutami. To najbardziej znaczące, ale niejedyne koszty związane z zatrudnieniem. Dochodzą także inne obciążenia, m.in. odpisy na zakładowy fundusz świadczeń socjalnych, koszty podroży służbowych, badań lekarskich pracowników oraz zapewnienia bezpieczeństwa i higieny pracy.

\section{Uwagi końcowe}

Przeprowadzanie audytu wewnętrznego wymaga ponoszenia kosztów, uzależnionych głównie od rodzaju wykorzystywanych zasobów. Teoretycznie możliwe byłoby scharakteryzowanie wyłącznie samych zasobów majątkowych lub kadrowych, jednak na sposób ich wykorzystania wpływają także inne czynniki - regulacje prawne i obowiązujące standardy oraz przyjęte zasady organizacji audytu. Sfera regulacyjna bezpośrednio oddziałuje na zasoby kadrowe, częściowo również na organizację. Jej wpływ na zaangażowany majątek ma z kolei charakter pośredni, ponieważ to, jakie aktywa wykorzystywane są do realizacji 
zadań audytowych, zależy głównie od organizacji pracy, a także zatrudnionego personelu. Stwierdzone zależności między wyodrębnionymi czynnikami zaprezentowano na rysun$\mathrm{ku} 1$.

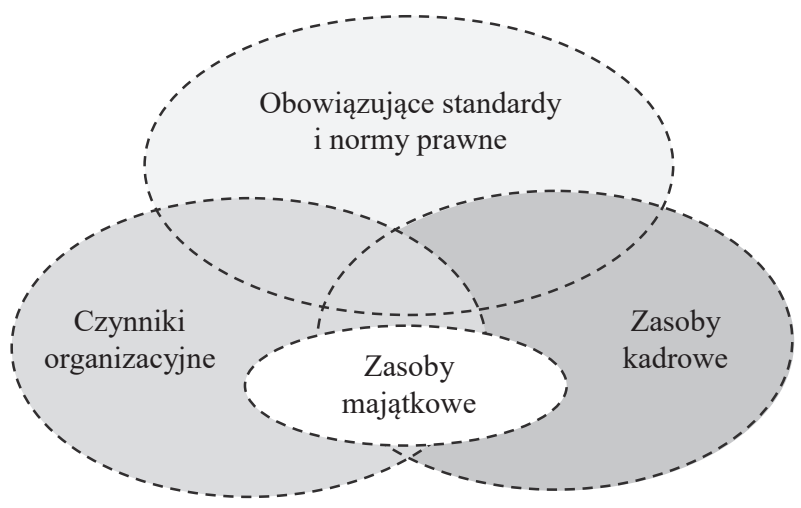

Rysunek 1. Zależności między czynnikami wpływającymi na efektywność audytu wewnętrznego Źródło: opracowanie własne.

Choć ustalenie kosztów audytu może okazać się skomplikowane, pracochłonne i kosztowne, to w praktyce jest niezbędne. Porównanie poziomu kosztów ze skwantyfikowanymi korzyściami uzyskanymi dzięki audytowi daje podstawy do pomiaru efektywności audytu wewnętrznego w każdej organizacji.

\section{Literatura}

Definicja audytu wewnętrznego, Kodeks etyki oraz Międzynarodowe standardy praktyki zawodowej audytu wewnętrznego (2016). Warszawa: Tłum. IIA - Polska. Pobrane z: http://www.iia.org.pl/o-nas/cele (24.05.2017).

Dubisz, S. (red.) (2003). Uniwersalny słownik języka polskiego, t. 3. Warszawa: Wydawnictwo Naukowe PWN.

Gabrusewicz, W., Kamela-Sowińska, A., Poetschke, H. (2002). Rachunkowość zarzadcza. Warszawa: PWE.

Gos, W. (2013). Regulacje w zakresie audytu wewnętrznego i kontroli zarządczej. W: T. Kiziukiewicz (red.), Audyt wewnętrzny w strukturze kontroli zarzadczej (s. 66-100). Warszawa: Difin.

Komunikat Ministra Rozwoju i Finansów z dnia 12 grudnia 2016 r. w sprawie standardów audytu wewnętrznego dla jednostek sektora finansów publicznych (Dz. Urz. Min. Rozw. i Fin. poz. 28).

Podręcznik audytu wewnętrznego w administracji publicznej (2003). Warszawa: Ministerstwo Finansów. Pobrane z: http://www.mf.gov.pl/c/document_library/get_file?uuid=d25de3cc-46cc-4765-8dfb-3872090 eaa18\&groupId= 764034 (26.05.2017).

Rozporządzenie Ministra Finansów z 29 grudnia 2009 r. w sprawie komitetu audytu (t.j. Dz.U. 2016 poz. 2049)

Rozporządzenie Ministra Finansów z 4 września 2015 r. w sprawie audytu wewnętrznego oraz informacji o pracy i wynikach tego audytu (Dz.U. poz. 1480 z późn. zm.).

Skrzypek, E. (2000). Jakość i efektywność. Lublin: Wydawnictwo UMCS.

Szymańska, H. (2013). Organizacja działu audytu wewnętrznego. W: T. Kiziukiewicz (red.), Audyt wewnętrzny w strukturze kontroli zarządczej (s. 287-324). Warszawa: Difin.

Ustawa z 12 września 2002 r. o normalizacji (t.j. Dz.U. 2015, poz. 1483).

Ustawa z 27 sierpnia 2009 r. o finansach publicznych (t.j. Dz.U. 2016, poz. 1870 z późn. zm.).

Ustawa z 29 września 1994 r. o rachunkowości (t.j. Dz.U. 2016, poz. 1047 z późn. zm.). 


\section{FACTORS INFLUENCING ON COSTS OF AN INTERNAL AUDIT}

Abstract: Purpose - Identification and characteristics the factors affecting the cost of audit activities that can be used to analyse the efficiency of an internal audit.

Design/methodology/approach - Analysis of literature, it was also applied general deductive method.

Findings - The factors that determine the costs of an internal audit are described in detail, the interdependencies between them are identified and the potential costs associated with an internal audit are listed.

Originality/value - Rational management of an internal audit requires knowledge of the costs associated with this sphere of activity. It is therefore necessary to shape their level in order to optimize them. It means that the objectives of the audit should be fully realized, while incurring the lowest costs.

Keywords: internal audit, efficiency, efficiency determinants, costs

\section{Cytowanie}

Bujak, A. (2017). Czynniki kształtujące koszty funkcjonowania audytu wewnętrznego. Finanse, Rynki Finansowe, Ubezpieczenia, 3 (87/1), s. 131-139. DOI: 10.18276/frfu.2017.87/1-12. 